\title{
Diversity of Anopheles spp. (Diptera: Culicidae) in an Amazonian Urban Area
}

\author{
IC Reis ${ }^{1,2}$, CT Codeço ${ }^{3}$, DCP CÂmara ${ }^{1,2}$, JJ Carvajal ${ }^{1,2}$, GR Pereira ${ }^{2}$, EC Keppeler ${ }^{4}$, NA Honório ${ }^{1,2}$ \\ 'Lab de Mosquitos Transmissores de Hematozoários, Instituto Oswaldo Cruz, Fiocruz, Rio de Janeiro, Brasil \\ ${ }^{2}$ Núcleo Operacional Sentinela de Mosquitos Vetores - Nosmove/Fiocruz, Rio de Janeiro, Brasil \\ ${ }^{3}$ Programa de Computação Científica -PROCC, Fiocruz, Rio de Janeiro, Brasil \\ ${ }^{4}$ Centro Multidisciplinar, Univ Federal do Acre, Rio Branco, Acre, Brasil
}

\section{Keywords}

malaria, urban area, Amazon, fish ponds, landscape, entomological surveillance

\section{Correspondence}

IC Reis, Núcleo Operacional Sentinela de Mosquitos Vetores - Nosmove/Fiocruz, Rio de Janeiro, Brasil; izabio2005@gmail.com

Edited by Rodrigo G Gonçalves - UnB

Received 18 July 2017 and accepted 25 January 2018

Published online: 22 February 2018

(C) Sociedade Entomológica do Brasil 2018

\begin{abstract}
The genus Anopheles encompasses several species considered as vectors of human infecting Plasmodium. Environmental changes are responsible for behavior changes in these vectors and therefore the pattern of malaria transmission. To better understand the dynamics of malaria transmission, this study aimed at identify the species of adult anophelines found in a malaria endemic urban area of the Amazon region, Mâncio Lima, located in the Acre State Brazil. Using Shannon-type light traps installed at 11 collection points near fish ponds, a total of 116 anophelines were collected belonging to nine species. Anopheles darlingi Root 1926 and An. albitarsis s.l. Lynch-Arribalzaga 1878 were the most abundant and predominant species. Despite the low number of captured adult anophelines, the occurrence of An. darlingi throughout all urban area and the presence of secondary vectors reinforce the need of a permanent and continuous entomological surveillance.
\end{abstract}

\section{Introduction}

Malaria is still considered one of the most important parasitic diseases in the tropics. It is caused by parasites of the genus Plasmodium, and transmitted by mosquitoes of the genus Anopheles. Anophelines have also been implicated as local or secondary vectors in the transmission cycles of microfilariae and arboviruses in Africa and Argentina (Mitchell et al 1985, Consoli \& Lourenço-de-Oliveira 1994, Diallo et al 2014). Anthropogenic environmental changes have altered the behavior of Anopheles spp. and consequently, patterns of malaria endemicity in the Amazon region.

Brazilian anophelines are diverse, with 55 described species of which 33 occur in the Amazon region (Tadei et al 1998, Rebêlo et al 2007). It must be noted that the anopheline fauna may be more diverse than found in this study of Rebêlo et al (2007). Several of the observed species are part of cryptical species complex, which share some degree of sympatry and have different levels of susceptibility to Plasmodium spp. (Mulamba et al 2014, Scarpassa et al 2016).

The main vector of malaria in the Amazon region is Anopheles (Nys.) darlingi Root 1926, but other species belonging to the subgenus Nyssorhynchus have also been incriminated as malaria vectors, including An. albitarsis s.l. Lynch-Arribalzaga 1878, An. deaneorum Rosa-Freitas 1989, An. braziliensis Chagas 1907, An. nuneztovari Galbadon 1940, An. oswaldoi s.l. Peryassú 1922, An. triannulatus Neiva \& Pinto 1922, An. strodei Root 1926, An. evansae Brèthes 1926, An. galvaoi Causey, Deane \& Deane, 1943, and An. aquasalis Curry 1932. The subgenus Anopheles has comparatively lower association with malaria transmission, for example, An. mattogrossensis Lutz \& Neiva 1911, An. peryassui Dyar \& Knab 1908 and An. mediopunctatus s.l. Theobald 1903, which are considered secondary vectors of malaria when compared to An. darlingi (Deane 1989, Branquinho et al 1996, Hiwat \& Bretas 2011). 
Anopheles darlingi occurs in about $80 \%$ of the Brazilian territory, and its distribution coincides with that of malaria (Hiwat \& Bretas 2011, Reis et al 2015a). Anopheles darlingi prefers large water bodies such as dams, and fish ponds for breeding (Vittor et al 2009, Hiwat \& Bretas 2011). In general, anophelines seek vertebrate hosts for blood meals throughout the night, with peaks in feeding activity at dusk and dawn (Consoli \& Lourenço-de-Oliveira 1994).

One the most malariogenic Amazonian municipalities of Brazil and South America, is Mâncio Lima, located in northwestern Acre State. The municipality registered 7763 autochthonous cases of malaria in 2016 (Annual Parasite Index - API 452 ), representing $23 \%$ of the total cases registered in the state. Approximately half of the cases notified in the municipality were located in the urban area (3791 cases; API 220.8) (Ministério da Saúde 2017).

The maintenance of malaria in Mâncio Lima has been attributed to the flooded landscape and the abundance of improperly managed fish ponds, which provide important productive breeding sites for malaria vectors, especially An. darlingi (Reis et al 2015a, b). To better understand the dynamics of malaria transmission, this study aims to identify adults of Anopheles species in urban area of Mâncio Lima near residences and fish ponds.

\section{Materials and Methods}

Mâncio Lima is one of the most malariogenic Amazonian municipalities in Brazil (upper limit: $7^{\circ} 06^{\prime} 46.60^{\prime \prime} \mathrm{S}, 73^{\circ} 59^{\prime}$ 19.54"W; inferior limit: $\left.7^{\circ} 46^{\prime} 51.41^{\prime \prime S}, 72^{\circ} 15^{\prime} 46.59^{\prime \prime} \mathrm{W}\right)$, located in northwestern Acre State. Acre is bordered by Bolivia in the southeast and Peru in the south and west, as well as the Brazilian states of Amazonas to the north and Rondônia to the east. Mâncio Lima has an approximate population of 15,206 inhabitants $\left(2.79 / \mathrm{km}^{2}\right)$, of which $57.6 \%$ is distributed in urban areas and $42.39 \%$ is distributed among rural or riverine areas (IBGE 2010).

The urban area is divided into seven census tracts and consists of an urban center with a fraction of the streets paved, with heavy commerce and a mostly residential peripheral area where the streets are not paved. The landscape is very heterogeneous, forming a mosaic of forest fragments, pastures, and developed areas, with abundant water bodies consisting mainly of the Japiim River, dams, streams, narrow channels, perennial and temporary pools, and fish ponds.

The climate in the state of Acre is warm and humid equatorial (Köppen-Geiger Af), with rainfall concentrated from November to April (annual values range from 1600 to $2750 \mathrm{~mm}$ ). The average annual temperature varies from 24.5 to $32^{\circ} \mathrm{C}$, with high relative humidity ( 90\%) (SEMA 2012). There are two distinct seasons: dry summers (May to October) and rainy winters (November to April) (Acre State Government).

Adult anophelines were captured using a Shannon light trap and mouth aspirators, by two trained technicians per trap at all times. The traps were installed in peridomiciliary areas at 11 collection points near fish ponds, distributed among 5 census tracts (Fig 1). The selection criterion for the households that received of the traps was to be close to fish ponds where the presence of immature Anopheles spp. was previously verified, as described in Reis et al (2015a, b). Traps remained in the field from 7:00 to 10:00 pm.

Species identification was carried out using the direct observation of morphological characters with a stereoscopic microscope, following the dichotomous keys by Consoli \& Lourenço-de Oliveira (1994) and by Forattini (2002). Demographic data of the municipality of Mâncio Lima were extracted from the Brazilian Institute of Geography and Statistics website (IBGE 2010) and the area calculation for census tracts was performed using the "Calculate Geometry" function in ArcGis 10.1 (ESRI ${ }^{\circledR}$ 2013). The environmental indicator "forested area per $\mathrm{km}^{2 \text { " }}$ was calculated per census tract by subtracting the total percentage of deforested area from the total land area. Land cover data for 2010 were provided by the Acre Technology Foundation. All fish ponds were georeferenced using GPS, and the number of fish ponds was extracted for each census sector. From this variable, we constructed the indicator "number of fish ponds per population of each sector."

To analyze temporal differences in anopheline captures, we used a chi-square test and a significance level of $<0.05$ using the R program ( $R$ Core Team) (R Development Core Team 2014). Ethical clearance was obtained from the Ethical Committee in Research (CEP 402/039) from the Oswaldo Cruz Foundation, Ministry of Health, Brazil.

\section{Results and Discussion}

During the months of July and October 2012 and February, July and December 2013, a total of 116 Anopheles spp. females were collected, 23 of which were only identifiable to genus due to damage to important morphological structures during collection and transportation to Rio de Janeiro, Brazil. The remaining 93 specimens belonged to 2 subgenera and 9 species, as follows: subgenus Nyssorhynchus (An. darlingi, An. albitarsis s.l., An. deaneorum, An. brasiliensis, An. lanei Galvão \& Amaral 1938, An. oswaldoi s.l., An. triannulatus s.l., An. mattogrossensis) and subgenus Lophopodomyia (An. gilesi, Neiva 1908) (Table 1). The most abundant species were An. albitarsis s.l. (27\%) and An. darlingi (26\%).

Anopheles darlingi was captured at all collection hours, peaking between 7:00 and 8:00 pm. There was a significant 
Fig 1 Distribution map for Anopheles spp. adults in the urban zone of Mâncio Lima, Acre from July 2012 to December 2013.
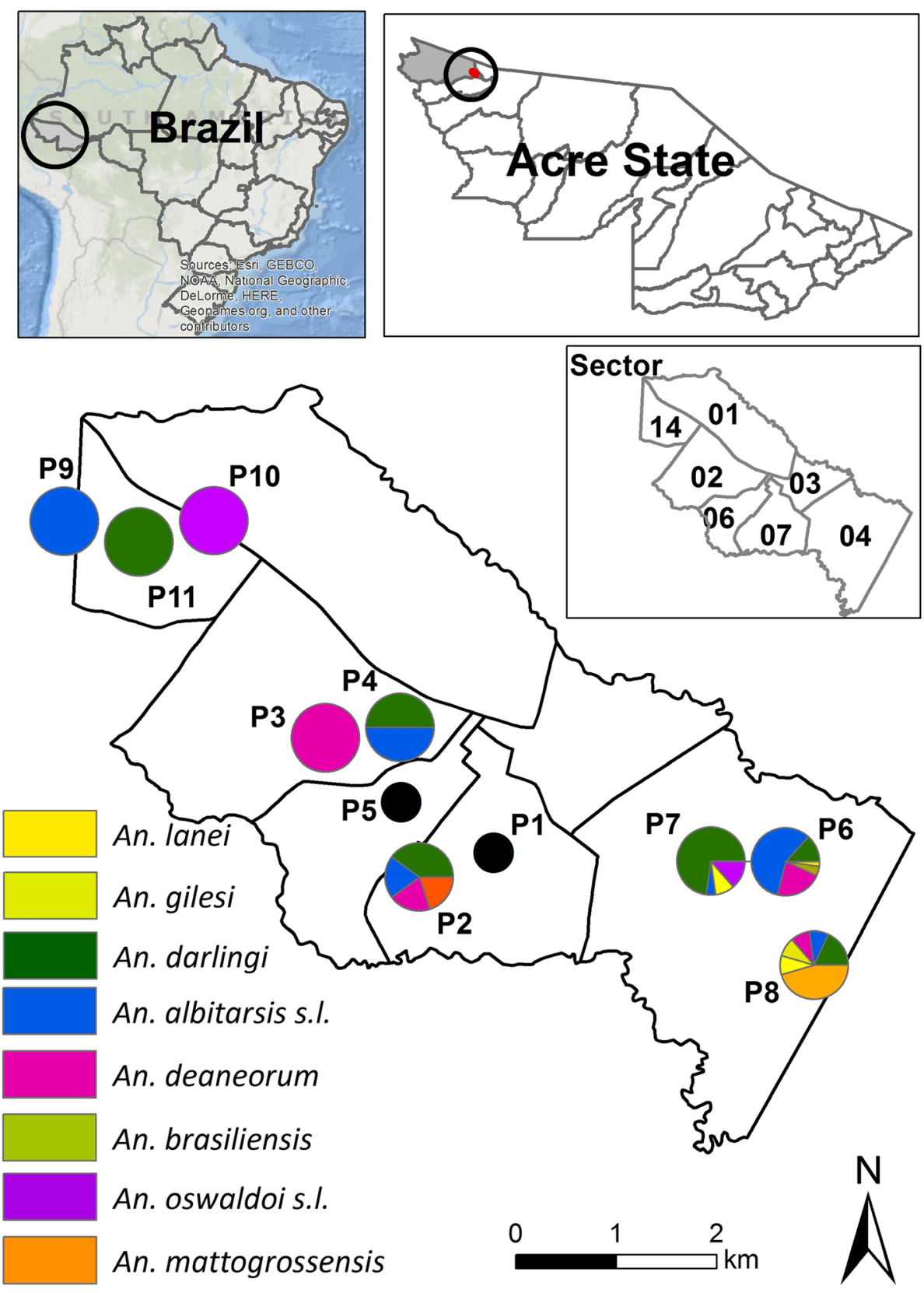

An. triannulatus s.l. difference between the number of Anopheles captured and time of capture $\left(X^{2}=89.2 ; p<0.0001\right)$. Ninety-two specimens were captured between 7:00 and 8:00 pm, including An. albitarsis s.l. (34\%), An. darlingi (25\%), and An. deaneorum (11\%). From 8:00 to 9:00 pm, 19 specimens were captured, in which An. darlingi was predominant with 6 specimens captured (32\%). From 9:00 to $10: 00$ pm, only 5 specimens were captured, 2 of which were An. darlingi. Our results agree with Silva-Vasconcelos et al (2002) which indicate the early hours of the night as the peak of feeding activity of Anopheles species. Anopheles darlingi and An. albitarsis s.l. were the most frequently captured species, occurring in more than $50 \%$ of the collection points. Anopheles mattogrossensis, An. triannulatus, and An. brasiliensis were the least common, each being captured at only one collection point (Table 1).

In the present study, the total number of captured Anopheles adults was low $(N=116)$, probably due to method used, compared to surveys conducted in other Brazilian areas. For example, Xavier \& Rebêlo (1999) used human bait for 12 collections throughout the year at São Luís Island in Raposa (Maranhão State), and captured 1407 adult 
Table 1 Total numbers of Anopheles spp. captured using Shannon traps in Mâncio Lima, Acre, from July 2012 to December 2013.

\begin{tabular}{|c|c|c|c|c|c|c|c|}
\hline Species & Collection points & July 2012 & October 2012 & July 2013 & October 2013 & December 2013 & Total \\
\hline An. darlingi & $P_{2}, P_{4}, P_{6}, P_{7}, P_{8}, P_{11}$ & 12 & 10 & 3 & 4 & 2 & 31 \\
\hline An.albitarsis s.l. & $\mathrm{P}_{2}, \mathrm{P} 4, \mathrm{P} 6, \mathrm{P7}, \mathrm{P} 8, \mathrm{P9}$ & 5 & 1 & 2 & 22 & 2 & 32 \\
\hline An.deaneorum & $\mathrm{P} 2, \mathrm{P} 3, \mathrm{P6}, \mathrm{P} 8$ & 3 & & 1 & 7 & 2 & 13 \\
\hline An. oswaldoi s.l. & P7, P10 & & 3 & 1 & & & 4 \\
\hline An. lanei & P7, P8 & 1 & 2 & & & & 3 \\
\hline An. gilesi & P6, P8 & 1 & & & 1 & & 2 \\
\hline An. mattogrossensis s.l. & $\mathrm{P} 8$ & 5 & & & & & 5 \\
\hline An. brasiliensis & P6 & & & & 2 & & 2 \\
\hline An. triannulatus s.l. & $\mathrm{P} 2$ & 1 & & & & & 1 \\
\hline
\end{tabular}

anophelines distributed among 6 species of the subgenus Nyssorhynchus. Maciel \& Missawa (2012) captured 3160 anophelines using human bait during evening collections (6:00 to 10:00 pm) in Porto Velho, Rondônia. On the other hand, Guimarães et al (1997) in Guairá, Paraná, demonstrated increased efficiency of Anopheles mosquitoes collection in Shannon traps (56.72\%) compared to human bait (43.28\%).

Our results showed a high species diversity of anopheline in an urban area and corroborate with previous studies. In the municipality of Anájas, Belém, six species of anophelines were collected with the predominance of An. darlingi ( $N=381$; 14.1\%) and An. oswaldoi ( $N=22,0.8 \%$ ) (Santos et al 2005). In the Vila Candelária, Rondônia, an urban river community, nine species of anophelines were captured, with predominance of An. darlingi $(N=2.131 ; 94 \%)$ and An. nuneztovari ( $N=87 ; 88.4 \%$ ) (Gil et al 2007). In the urban area of Boa Vista, Roraima, seven species were captured with predominance of An. darlingi and An. albitarsis s.l. (SilvaVasconcelos et al 2002, Póvoa et al 2006). Additionally, Póvoa et al (2006) showed that in some districts of Boa Vista, An. albitarsis E (a member of the Albitarsis complex) was significantly more abundant than An. darlingi and was incriminated as the main vector of malaria. However, these authors highlighted the strong role of An. darlingi in malaria transmission even at low densities, as occurrence of this species is typically associated with areas of high malaria prevalence.

In Mâncio Lima, census sector 04 had the highest richness and abundance of captured specimens (Fig 1, Table 2). This sector encompasses more than $50 \%$ of the deforested territory within the urban zone while, as well as $1 / 3$ of the fish ponds ( 4 fish ponds/100 inhabitants). In the others sectors, the fish ponds density was $<4$ fish ponds/100 inhabitants. Fish ponds have been incriminated as the main breeding sites
Table 2 Environmental and sociodemographic characteristics of experimental census tracts in the urban center of Mâncio Lima, Acre.

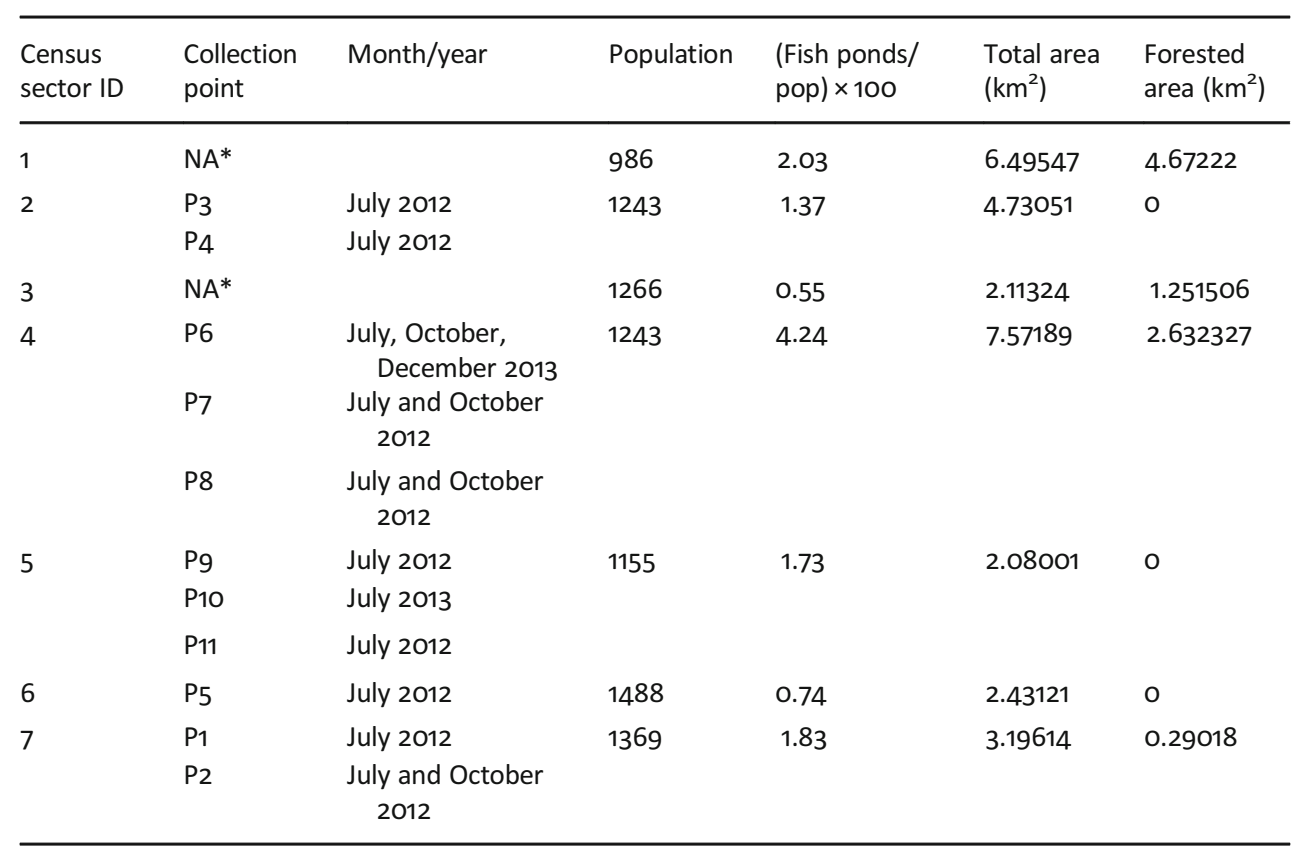

$N A^{*}$ not sampled 
for immature forms of Anopheles species (Reis et al 2015a) and are capable of supporting anopheline populations throughout the year if proper management practices are not maintained (Reis et al 2015b).

This study reinforces the importance of keeping updated the knowledge of anopheline fauna in areas with malaria transmission, especially in places where urban transmission is known. Many urban areas in the Amazon, such as Mâncio Lima, have been suffering large landscape and ecological transformations, such as the large scale development of aquaculture that changes the temporal and spatial receptivity of the area for anophelines. Despite the low number of adult anophelines captured, our study evidences a diverse population of anophelines, composed not only by the main malaria vector in the Amazonian region (An. darlingi) but also by several secondary vectors, such as An. albitarsis s.l. and others. These results highlight the necessity of a continuous entomological surveillance in the area to inform control strategies.

Acknowledgements We are grateful for the support from the Coordenação de Aperfeiçoamento de Pessoal de Nível Superior (CAPES). We thank the Secretária Municipal de Saúde de Mâncio Lima and the Gerência de Endemias de Mâncio Lima, Acre. In addition, we thank Teresa Fernandes Silva do Nascimento, Jerônimo Augusto Fonseca Alencar, Neilson Melo, José Raimundo Silva de Moura, Andrealis Santos de Souza, Glaucio Pereira Rocha, Célio da Silva Pinel, Fernanda Christina Morone Rodrigues, and Mauro Menezes Muniz for mosquito collections in the field and/or help in the laboratory and Tamara Nunes de Lima Camara for previous corrections on the manuscript.

Financial support Financial support was provided by the Conselho Nacional de Desenvolvimento Científico e Tecnológico (CNPq) (Processos 484027/2012-3, 479977/2008-9, 471295/2011-6, 552746/ 2011-8); Fundação de Amparo à Pesquisa do Estado do Rio de Janeiro (FAPERJ) (Processo E-26/111.50o/2011), Coordenação de Aperfeiçoamento de Pessoal de Nível Superior (CAPES) (Processo 334113-5 do Programa Ciência Sem Fronteira de ICR); Universidade Federal do Acre, FUNTAC (FDCT 03/2011 Processo 04/2012), FAPAC (PPSUS Processo n. 14/2013) and Programa de Pós-graduação em Medicina Tropical, Fundação Oswaldo Cruz (Fiocruz, RJ).

\section{Compliance with Ethical Standards}

Conflict of Interest The authors declare that they have no conflict of interest.

\section{References}

Branquinho MS, Araújo MS, Natal D, Marreli MT, Rocha RM, Taveira FAL, Kloetzel JK (1996) Anopheles oswaldoi a potencial malária vector in Acre, Brazil. Trans Royal Soc Trop Med Hyg 90(3):233. https://doi. org/10.1016/SoO35-9203(96)90225-4
Consoli RAGB, Lourenço-de-Oliveira R (1994) Principais mosquitos de importância sanitária no Brasil. Fiocruz, Rio de Janeiro, p 228. https://doi.org/10.7476/9788575412909

Deane LM (1989) A cronologia da descoberta dos transmissores da malária na Amazônia brasileira. Mem Inst Oswaldo Cruz 84(suppl 4):149-156. https://doi.org/10.1590/S0074-02761989000800030

Diallo D, Sall AA, Diagne CT, Faye O, Faye O, Ba Y, Hanley KA, Buenemann M, Weaver SC, Diallo M (2014) Zika virus emergence in mosquitoes in southeastern Senegal, 2011. PLoS One 9(10):e109442. https://doi.org/10.1371/journal.pone.0109442

Forattini OP (2002) Culicidologia médica, vol 2. Editora da Universidade de São Paulo, São Paulo, p 860

Gil LHS, Tada MS, Katsuragawa TH, Ribolla PE, da Silva LH (2007) Urban and suburban malaria in Rondônia (Brazilian Western Amazon) II. Perennial transmissions with high anopheline densities are associated with human environmental changes. Mem Inst Oswaldo Cruz 102(3): 271-276. https://doi.org/10.1590/S0074-02762007005000013

Guimarães AE, Mello RPD, Lopes CM, Alencar J, Gentil C (1997) Prevalência de anofelinos (Diptera: Culicidae) no crepúsculo vespertino em áreas da Usina Hidrelétrica de Itaipu, no Município de Guairá, Estado do Paraná, Brasil. Mem Inst Oswaldo Cruz 92(6):745-754. https://doi.org/10.1590/S0074-02761997000600004

Hiwat H, Bretas G (2011) Ecology of Anopheles darlingi root with respect to vector importance: a review. Parasit Vectors 4:1-13

Instituto Brasileiro de Geografia e Estatística (IBGE) (2010) Censo demográfico. www.ibge.gov.br Accessed 26 Jan 2017

Maciel GBML, Missawa NA (2012) Descrição de fauna anofélica em área endêmica de malária no Município de Colniza, estado de Mato Grosso, Brasil. Epidemiol Serv Saúde 21(1):141-148. https://doi.org/ $10.5123 /$ S1679-49742012000100014

Ministério da Saúde (2017) Sistema de Informação em Vigilância Epidemiológico da Malária (SIVEP-Malaria). http://portalwebo4. saude.gov.br/sivep_malaria/. Accessed 26 Jan 2017

Mitchell CJ, Monath TP, Sabattini MS, Cropp CB, Daffner JF, Calisher CH, Jakob WL, Christensen HA (1985) Arbovirus investigations in Argentina. Am J Trop Med Hyg 34(5):945-955. https://doi.org/10. 4269/ajtmh.1985.34.945

Mulamba C, Irving H, Riveron JM, Mukwaya LG, Birungi J, Wondji CS (2014) Contrasting Plasmodium infection rates and insecticide susceptibility profiles between the sympatric sibling species Anopheles parensis and Anopheles funestus s.s: a potential challenge for malaria vector control in Uganda. Parasit Vectors $7(1): 71$. https://doi.org/10. 1186/1756-3305-7-71

Póvoa MM, Souza RTL, Lacerda RNL, Rosa ES, Galiza D, Souza JR, Wirtz RA, Schlichting CD, Conn JE (2006) The importance of Anopheles albitarsis $\mathrm{E}$ and $A n$. darlingi in human malaria transmission in Boa Vista, state of Roraima, Brazil. Mem Inst Oswaldo Cruz 101(2):163168. https://doi.org/10.1590/S0074-02762006000200008

R Development Core Team (2014) R: A Language and Environment for statistical computing. the R Foundation for Statistical Computing, Viena, Austria

Rebêlo JMM, Moraes JLP, Alves GA, Leonardo FS, Rocha RV, Mendes WA, Costa E, Câmara LEMB, Silva MJA, Pereira YNO, Mendonça JAC (2007) Distribuição das espécies do gênero Anopheles (Diptera: Culicidae) no estado do Maranhão, Brasil. Cad Saúde Pública 23(12): 2959-2971. https://doi.org/10.1590/S0102-311X2007001200017

Reis IC, Honório NA, Barros FSM, Barcellos C, Kitron U, Camara DCP, Pereira GR, Keppeler EC, Silva-Nunes M, Codeço CT (2015a) Epidemic and endemic malaria transmission related to fish farming ponds in the Amazon frontier. PLoS One 10(9):e0137521. https://doi.org/10.1371/ journal.pone.0137521

Reis IC, Codeço CT, Degener CM, Keppeler EC, Muniz MM, Oliveira FGS, Cortês JJC, Monteiro AF, Souza CAA, Rodrigues FCM, Maia GR, Honório NA (2015b) Contribution of fish farming ponds to the production of immature Anopheles spp. in a malaria-endemic Amazonian town. Malar J 14(1):452. https://doi.org/10.1186/s12936-015-0947-1 
Santos RC, Sucupira IMC, Lacerda RNL, Fayal AS, Póvoa MM (2005) Inquérito entomológico e infectividade durante epidemia de malária no município de Anajás, Estado do Pará. Rev Soc Bras Med Tropical 38:2002-2204

Scarpassa VM, Cunha-Machado AS, Saraiva JF (2016) Evidence of new species for malaria vector Anopheles nuneztovari sensu lato in the Brazilian Amazon region. Mal J 15(1):205. https://doi.org/10.1186/ s12936-016-1217-6

Secretaria de Estado de Meio Ambiente (SEMA) (2012) Programa de arborização urbana do estado do Acre. Rio Branco, SEMA, p 51

Silva-Vasconcelos A, Kato MY, Mourão EN, de Souza RT, Lacerda RN, Sibajev A, Tsouris P, Póvoa MM, Momen H, Rosa-Freitas MG (2002) Biting indices, host-seeking activity and natural infection rates of anopheline species in Boa Vista, Roraima, Brazil from 1996 to 1998. Mem Inst Oswaldo Cruz 97(2):151-161. https://doi.org/10.1590/ S0074-02762002000200002
Tadei WP, Dutary TB, Santos JM, Scarpassa VM, Rodrigues IB, Rafael MS (1998) Ecologic observations on anopheline vectors of malaria in the Brazilian Amazon. Am J Trop Med Hyg 59(2):325-335. https://doi.org/ 10.4269/ajtmh.1998.59.325

Vittor AY, Pan W, Gilman RH, Tielsch J, Glass G, Shields T, SánchezLozano W, Pinedo VV, Salas-Cobos E, Flores S, Patz JA (2009) Linking deforestation to malaria in the Amazon: characterization of the breeding habitat of the principal malaria vector, Anopheles darlingi. Am J Trop Med Hyg 81(1):5-12

Xavier MMSP, Rêbelo JMM (1999) Espécies de Anopheles (Culicidae, Anophelinae) em área endêmica de malária, Maranhão, Brasil. Rev Saude Pub 33(6):535-541. https://doi.org/10.1590/So03489101999000600003 